\begin{tabular}{l|l}
\hline Potaice & e-ISSN: 2655-9404 \\
Vol. 2 No. 3, Oktober 2019 & DOI: 10.20473/ntr.v2i3.14721 \\
\hline
\end{tabular}

Article history: Submitted 5 September 2019 ; Accepted 19 September 2019; Available online 1 October 2019.

\title{
Perampasan Obyek Fidusia dan Akibat Hukumnya
}

\author{
Memet Achirius Sjafar \\ achirius77@gmail.com \\ Universitas Airlangga
}

\begin{abstract}
The choice of a person using a fiduciary guarantee institution for his business interests reflects that the fiduciary guarantee institution is closely related to business activities, but there are times when the debtor or other party uses a fiduciary object as a means to commit a crime, consequently if the crime can be proven by a judge, then it is possible that the fiduciary object the said state is seized for the State, the settlement of which is carried out by being sold at auction using the type of auction of the booty. The seizure of fiduciary objects by the State will have legal consequences on creditors and debtors as well as on the auction winners or buyers. The legal consequence for the creditor is the loss or elimination of the inherent material rights attached to him. For the debtor due to the law, he must settle his obligations arising from the principal agreement that has been agreed with the creditor even though the fiduciary object is not in his possession. If the execution of the spoils is carried out by the Prosecutor's Office, then the creditor sues the auction results to the Court and the court grants the decision to declare the results of the auction null and void. by law, property rights over the object that he bought ends too. The legal consequences of the aforementioned parties are the result of empty norms or the absence of statutory regulations governing the seizure of fiduciary objects by the State and the auction of the execution of looted goods which were previously fiduciary objects.
\end{abstract}

Keywords: Fiduciary Objects; State Appropriation; Auction; Creditors; Buyers.

\begin{abstract}
Abstrak
Pilihan seseorang menggunakan lembaga jaminan fidusia untuk kepentingan bisnisnya mencerminkan bahwa lembaga jaminan fidusia terkait erat dengan kegiatan bisnis, namun ada kalanya debitur atau pihak lain menggunakan obyek fidusia sebagai sarana untuk melakukan kejahatan, akibatnya jika kejahatan tersebut dapat dibuktikan oleh Hakim, maka dimungkinkan bahwa obyek fidusia tersebut dinyatakan dirampas untuk Negara yang penyelesaiannya dilakukan dengan dijual secara dilelang menggunakan jenis lelang eksekusi barang rampasan. Perampasan objek fidusia oleh Negara akan menimbulkan akibat hukum terhadap kreditor dan debitor maupun kepada pemenang lelang atau pembeli. Akibat hukum bagi kreditor adalah hilannya atau terhapusnya hak hak kebendaan yang melekat pada dirinya. Bagi debitor akibat hukumnya adalah dia harus menyelesaikan kewajibannya yang timbul dari perjanjian pokok yang telah disepakati bersama dengan kreditor sekalipun obyek fidusia tidak dalam penguasaannya. Jika eksekusi terhadap barang rampasan dilaksanakan oleh Kejaksaan, kemudian kreditor menggugat hasil lelang tersebut ke Pengadilan dan pengadilan mengabulkan yang dalam putusannya menyatakan hasil lelang batal demi hukum, maka pihak yang paling dirugikan adalah pemenang lelang atau pembeli yang beritikat baik, karena apabila hasil lelang dinyatan batal demi hukum, berakhir pula hak milik atas benda yang dibelinya. Akibat hukum yang menimpa pihak-pihak tersebut di atas merupakan akibat dari norma kosong atau tidak adanya peraturan perundang-undangan yang mengatur perampasan obyek fidusia oleh Negara dan lelang eksekusi barang rampasan atas barang yang sebelumnya menjadi obyek fidusia.
\end{abstract}

Kata Kunci: Obyek Fidusia; Perampasan Oleh Negara; Lelang, Kreditor; Pembeli. 


\section{Pendahuluan}

Konsep dasar fidusia adalah keprcayaan sesuai dengan asal kata fidusia atau fides yang berarti kepercayaan. Kepercayaan inilah yang melatar belakangi hubungan hukum antara kerditor dengan debitor dalam perjanjian fidusia. Munculnya lembaga jaminan fidusia, konon karena disebabkan adanya masyarakat membutuhkan benda untuk kegiatan bisnis namun masyarakat tersebut tidak mempunyai kemampuan yang cukup untuk membeli secara tunai sehingga masyarakat tersebut mengajukan pinjaman kepada kreditor namun benda untuk kegiatan bisnis dan dijadikan jaminan atas kreditnya tidak dibawah penguasaan kreditor tetapi dalam penguasaan seorang debitor. Masyarakat membutuhkan kredit pada bank dengan menjaminkan benda bergerak akan tetapi benda yang dijadikan obyek jaminan masih dikuasai debitor untuk diperlukan dalam melanjutkan usahanya. ${ }^{1}$ Pilihan seseorang menggunakan lembaga jaminan fidusia untuk kepentingan bisnisnya mencerminkan bahwa lembaga jaminan fidusia erat kaitannya dengan dunia bisnis, obyek jaminan fidusia dapat digunakan oleh deditor fidusia untuk menjalankan bisnisnya, kendaraan bermotor, mesin-mesin adalah roda penggerak agar bisnis yang digelutinya tetap berjalan dan selalu mendatangkan keuntungan.

Pada sisi yang berbeda, obyek fidusia kerap disalah gunakan oleh debitor maupun pihak lain, obyek fidusia sering digunakan sebagai sarana melakukan tindak pidana atau kejahatan, Apabila Pengadilan menyatakan tindak pidana tersebut terbukti dapat dipastikan bahwa obyek fidusia dinayatakan dirampas untuk Negara. Perampasan obyek fidusia oleh Negara berakibat hukum yang sangat besar dan dahsyat yang pasti menimpa kreditor, debitor serta pihak lainnya yaitu pemenang/pembeli lelang eksekusi barang rampasan. Perampasan obyek fidusia akan merontokan kokohnya Hak Kebendaan yang melekat pada tubuh Kreditur, selain itu kekuatan posisi hak milik atas obyek fidusia lambat laut akan sirna seiring berhalihnya hak milik tersebut kepada Negara, sebaliknya debitor akan kehilangan benda sekaligus hak atas benda yang dirampas oleh Negara, pada ruang yang berbeda lembaga lelang sebagai mediator penjualan barang

${ }^{1}$ Leonora Bakarbessy Trisadini Prasastinah Usanti, Hukum Jaminan (Revka Petra Media 2016).[113]. 
rampasan tidak lagi mempunyai keunggulan dan jaminan kepastian hukum terhadap pemenang lelang atau pembeli apabila kreditor menggugat hasil lelang, kemudian putusan Pengadilan yang inkracht. Menyatakan hasil lelang batal demi hukum, dampak pembatalan hasil lelang adalah berakhirnya hak milik dari pembeli atas benda yang dibelinya secara lelang tersebut. Berdasarkan uraian diatas, maka dalam penelitisan hukum ini digunakan judul "Perampasan Obyek Fidusia dan Akibat Hukumnya".

\section{Kedudukan Kreditor dan Status Obyek Fidusia yang dirampas untuk Negara}

Sebutan Hak Jaminan kebendaan (juga disebut dengan istilah hak kebendaan bercorak jaminan) membersitkan makna bahwasanya hak jaminan itu melekat atau menindih suatu benda, dan benda itu tentunya milik debitor, dan juga hak jaminan tidak melekat pada seluruh benda milik debitor mengingat hak jaminan yang melekat pada segenap harta debitor dikuasai oleh pasal 1131 BW. ${ }^{2}$

Hak jaminan hanya dibebankan atau dilekatkan pada terhadap benda yang dijaminkan sesuai dengan kesepakatan Kreditor dan Debitor yang tertuang dalam sebuah perjanjian. Oleh sebab itu perjanjian tersebut dinamakan sebagai perjanjian jaminan. Mengingat perjanjian jaminan yang bersangkutan obyeknya benda maka perjanjian dimaksud termasuk sebagai perjanjian kebendaan yang akan melahirkan hak kebendaan bercorak jaminan (hak Jaminan kebendaan). ${ }^{3}$

Perjanjian jaminan kebendaan merupakan perjanjian accesoir/ikutan/ tambahan, yaitu senantiasa dikaitkan dengan perjanjian pokoknya, sehingga kedudukannya bergantung pada perjanjian pokoknya. Akibat hukum dari perjanjian accesoir yaitu (1) Hapusnya bergantung pada perjanjian pokok (2) Jika perjanjin pokok batal maka ikut batal (3) Jika perjanjian pokoknya beralih karena cessie, subrigasi, maka ikut beralih juga tanpa danya penyerahan khusus. Perjanjian Pokok dapat berupa perjanjian pinjam meminjam, perjanjian kredit, perjanjian pemborongan, Perjanjian Pembiayaan Konsumen. ${ }^{4}$

\footnotetext{
${ }^{2}$ Isnaeni Moch, Pengantar Hukum Jaminan Kebendaan (PT Revka Petra Media 2016).[117]. ${ }^{3}$ ibid. [117].

${ }^{4}$ Trisadini Prasastinah Usanti (n 1).Op.Cit.[39].
} 
Suatu benda yang dimiliki oleh seseorang baik benda bergerak maupun benda tidak bergerak dapat diikat dengan sejumlah utang. Pembebanan atas benda bersangkutan memakai lembaga jaminan jenis yang mana adalah ditentukan dengan macam benda yang dijadikan obyek jaminan. ${ }^{5}$ Lembaga Jaminan difasilitasi oleh lembaga Gadai sebagai mana diatur dalam 1150-1160 BW dan Lembaga Jaminan Fidusia sebagai mana diatur dalam Undang-Undang Nomor 42 Tahun 1999. Agar tidak bias arah, maka pembahasan lebih difokuskan lembaga jaminan fidusia.

Lembaga jaminan fidusia adalah bagian dari Jaminan Kebendaan (zakerlijke zakerheid) yang peraturan perundang-undangannya berada di luar Burgerlijk Wetbook (BW), Jaminan Fidusia diatur dalam UU Nomor 42 Tahun 1999 tentang Jaminan Fidusia (selanjutnya disebut UUJF). Lahirnya UUJF didasarkan atas pertimbangan adanya kebutuhan yang sangat besar dan terus meningkat bagi dunia usaha atas tersedianya dana namun tidak tersedianya ketentuan hukum yang jelas dan lengkap yang mengatur mengenai lembaga jaminan fidusia, Yurisprudensi. ketentuan hukum yang mengatur lembaga jaminan fidusia sebelum lahirnya UUJF. Fidusia sangat erat hubungannya dengan kegiatan bisnis, sehingga kelahiran dan kehadiran UUJF ini disambut dengan gegap gempita oleh kalangan dunia bisnis.

Pasal 1 ayat (1) UUJF menyatakan Fidusia adalah pengalihan hak kepemilikan suatu benda atas dasar kepercayaan dengan ketentuan bahwa benda yang hak kepemilikannya dialihkan tersebut tetap dalam penguasaan pemilik benda. Pengalihan hak kepemilikan dalam tententuan di atas tidak bermakna levering sebagaimana dalam perjanjian jual beli, tetapi merupakan penyerahan benda dengan cara constitutum possessorium (benda yang dialihkan tetap dikuasai oleh penjual dalam hal ini penerima fidusia), cara ini untuk menjamin benda tersebut atas utang dan melindungi kreditur atau penerima fidusia apabila debitur atau pemberi fidusia cidera janji.

Lembaga Jaminan Fidusia merupakan jalan keluar terbaik bagi masyarakat yang membutuhkan suatu barang atau benda untuk dipergunakan sebagai sarana untuk menjalankan bisnisnya namun tidak mampu untuk membeli secara tunai.

5 ibid.[37]. 
Selain itu adanya asas inbezitstelling dalam Lembaga Gadai, membuat lembaga ini tidak dapat menjadi fasilitaor antara pemberi gadai dan penerima gadai, keadaan yang sama terjadi pada lembaga jaminan hipotek yang diatur dalam BW ataupun hak tanggungan tidak dapat memfasilitasi karena masyarakat kecil tidak memiliki lahan atau benda yang memenuhi syarat untuk untuk dijadikan agunan.

Pasal 1 angka 2 UUJF menyatakan bahwa "Jaminan Fidusia adalah hak jaminan atas benda bergerak baik yang berwujud maupun yang tidak berwujud; dan benda tidak bergerak khususnya bangunan yang tidak dapat dibebani hak tanggungan sebagaimana dimaksud dalam Undang-undang Nomor 4 Tahun 1996 tentang Hak Tanggungan yang tetap berada dalam penguasaan Pemberi Fidusia, sebagai agunan bagi pelunasan utang tertentu, yang memberikan kedudukan yang diutamakan kepada Penerima Fidusia terhadap kreditor lainnya. Pasal ini merupakan penagasan bahwa dari jaminan fidusia akan lahir hak kebendaan, ciri-ciri unggul hak kebendaan hal ini dinyatakan tegas dalam Undang-Undang Jaminan Fidusia pada pasal-pasal sebagai berikut :

1. Pasal 20 UUJF menegaskan berlakunya asas droit de suite (hak mengikuti).

2. Asas droit de preference diakomodir pada Pasal 1 angka 2 UUJF.

3. Asas Prioritas ditegaskan dalam pasal 27 ayat (1) Jo. Pasal 28 UUJF.

Pasal 1 angka 2 UUJF yang menyatakan bahwa obyek fidusia terdiri dari benda bergerak baik yang berwujud maupun yang tidak berwujud, dan benda tidak bergerak khususnya bangunan yang tidak dapat dibebani hak tanggungan sebagaimana dimaksud dalam Undang-undang Nomor 4 Tahun 1996 tentang Hak Tanggungan.

Benda bergerak dan tidak bergerak (pasal 504 BW). Makna benda bergerak adalah setiap benda yang dapat dipindah-pindah dari satu tempat ketemmpat lain sedangkan benda tidak bergerak pada dasarnya adalah benda yang tidak dapat dipindah-pindah. ${ }^{6}$

Benda bergerak yang dimaksud dibagi menjadi benda berujud dan benda tidak berujud (Pasal 503 BW). Benda berujud merupakan jenis benda yang kasat indera,

${ }^{6}$ Moch (n 2).Op.Cit.[20]. 
sedang benda tidak berujud adalah benda yang tidak dapat diamati secara alamiah. ${ }^{7}$

Perkembangan peradaban zaman dan kemajuan teknologi secara langsung atau tidak langsung membawa permasalahan baru di bidang hukum yaitu munculnya pembagian jenis benda yaitu benda terdaftar dan benda tidak terdaftar, pembagian untuk menentukan kedudukan hukum benda terdaftar menyangkut bidang levering, tanda bukti kepemilikan.

Adapun yang dimaksud dengan benda bergerak yang berwujud, dapat diklasifikasikan sebagai berikut: ${ }^{8}$

1. Kendaraan Bermotor, baik kendaraan bermotor R2 atau R4 bahkan saat ini kendaraan R3 merupakan bagian objek jaminan fidusia

2. Mesin-mesin

Mesin-mesin yang karena sifatnya melekat dengan tanah, sehingga dianggap sebagai benda tetap atau benda tidak bergerak, dan mesin-mesin yang karena sifatnya dengan mudah dapat dipindahkan, sehingga dianggap sebagai benda tidak tetap atau bergerak.

3. Benda Persediaan

Benda Persediaan adalah benda yang selalu perubah-ubah dan atau tidak tetap dan dipergunakan sebagai objek dalam usaha.

Sedangkan yang dimaksud dengan bernda bergerak yang tidak berwujud, yaitu piutang dagang. Agunan yang titerima tersebut harus mempunyai nilai hasil ekonomis yang tinggi dalam arti bahwa hak atas barang tersebut harus dapat langsung di ikat oleh bank sebagai kreditur preferent, sehingga dalam waktu singkat agunan tersebut dengan mudah dikonversikan kedalam bentuk uang untuk menyelesaikan kredit apabila dianggap perlu oleh bank.

UUJF memberikan kemudahan kepada penerima fidusia untuk melakukan eksekusi atas jaminan fidusia. Dasar pelaksanaan eksekusi Jaminan Fidusia diatur dalam pasal Pasal 15 dan Pasal 29 UUJF, merujuk pada pasal 15 eksekusi dapat

7 ibid. [20].

${ }^{8}$ Marulak Pardede, Implementasi Jaminan Fidusia Dalam Pemberian Kredit Di Indonesia 2006 (Badan Pembinaan Hukum Nasional Departemen Hukum Dan HAM-RI 2006).[47]. 
dilakukan dengan 2 (dua) cara yaitu:

1. Eksekusi dengan title eksekutorial

Eksekusi dapat langsung dilaksanakan melalui Pengadilan dibawah pimpinan Ketua Pengadilan Negeri atau harus ada fiat eksekusi dari Ketua Pengadilan Negeri Karena Sertifikat Fidusia dianggap sama dengan putusan Pengadilan yang mempunyai kekuatan hukum tetap.

2. Parate Eksekusi adalah pelaksanaan prestasi yang dilakukan sendiri oleh kreditur (berpiutang) tanpa melalui hakim.

Sedangkan menurut pasal 29 UUJF pelaksanaan eksekusi selain mengacu pada pasal 15, penerima fidusia dapat menjual benda dengan cara lelang dan dapat mejual dibawah tangan dengan syarat ada kesepakatan pemberi dan penerima fidusia.

Karena sifatnya accessoir atau ikuta, maka dalam hal hapusnya jaminan fidusia UUJF menyatakan hapusnya jaminan fidusia karena :

1. Hapusnya utang yang dijamin fidusia;

2. Pelepasan hak atas jaminan fidusia oleh debitor;

3. Musnahnya benda yang menjadi objek jaminan fidusia.

Penjajian jaminan fidusia merupakan perjanjian jaminan hak kebendaan yang melahirkan hak kebendaan, hak kebendaan ini bersanding kokoh dengan penerima fidusia, kedudukan kreditor atau penerima fidusia sebagai pemegang hak kebendaan dijamin oleh pasal 1 angka 2 UUJF, namun keutamaan yang diberikan Undang-Undang akan sirna ketika adanya Putusan Pengadilan yang inkracht yang menyatakan obyek fidusia dirampas untuk Negara, perampasan obyek fidusia oleh Negara berakibat hukum terhapusnya hak kebendaan dari penerima fidusia dan terjadinya peralihan hak dari pemilik benda kepada Negara, berkaitan dengan hal tersbut yang menjadi pertanyaan bagaimana kedudukan kreditor terhadap obyek fidusia yang dirampas Negara, mengingat UUJF tidak mengatur secara tegas apakah Perampasan obyek jaminan fidusia oleh Negara menyebabkan hapusnya hak kebendaan.

Terlepas dari tidak tegasnya ketentuan tentang perampasan obyek fidusia oleh Negara, putusan Pengadilan tentang perampasan obyek fidusia oleh Negara 
harus dilaksanakan. Kasus perampasan obyek fidusia oleh Negera sudah banyak terjadi di indonesia.

Banyak kasus perampasan obyek fidusia oleh Negara terjadi di negeri tercinta ini, yang menyebabkan timbulnya sengketa yang berkepanjangan antara Penerima Fidusia dengan Pemerintah Cq. Kejaksaan RI. Salah satu kasus perampasan obyek fidusia oleh Negara terjadi di wilayah hukum Pengadilan Negeri Ketapang. Dalam kasus tersebut obyek fidusia berupa 1 (satu) mobil truck merek Mitshubishi dengan Nomor. Polisi : D-8474- YQ warna putih dengan Nomor Rangka : MHMFE74P4DK066051 dan Nomor Mesin 4D34TJ27693 (selanjutnya disebut kendaraan), Berdasarkan putusan Pengadilan Negeri Ketapang dalam perkara tindak pidana yang tercatat dalam register Nomor 95/Pid.Sus/2015.PN.Ktp. tanggal 15 Juni 2015 dengan terdakwa atas nama HENDI HERIYADI Bin MAT JEMAN (selanjutnya disebut terdakwa) dirampas untuk Negara. Dalam perkara tersebut terdakwa terbukti secara sah dan meyakinkan melakukan tindak pidana dengan sengaja mengangkut hasil hutan berupa kayu yang tidak dilengkapi bersama-sama Surat Keterangan Sahnya Hasil Hutan (SKSHH) dengan menggunakan sarana pengankutan berupa kendaraan dimaksud dan di atas kendaraan tersebut sudah letakkan jaminan fidusia. Peletakan jaminan fidusia diatas kendaraan tersebut berdasarkan perjanjian jaminan fidusia Nomor. 020313200545, tanggal 28 Maret 2013 antara PT. Adira Dinamika Multi Finance selaku penerima fidusia dengan Wawan (selaku pemberi fidusia) dan jaminan fidusia tersebut telah didaftarkan dengan Sertifikat Fidusia Nomor W11.089693.AH.05.01 Tahun 2013 dari Pemberi Kuasa Wawan kepada PT. Adira Dinamika Multi Finance, Tbk, Cabang Bandung, atas objek perjanjian pembiayaan 020313200545 tertanggal 28 Maret 2013 atas nama Wawan. Karena merasa keberatan terhadap putusan Pengadilan Negeri Ketapang dalam perkara atas nama terdakwa, penerima fidusia mengajukan gugatan perlawanan terhadap Pemerintah Cq. Kejaksaan RI. Pernerima Fidusia selaku Pelawan mengajukan dalil perlawanan yang pada pokoknya menyatakan bahwa:

1. Pelawan adalah pemilik sah dari kendaran tersebut berdasarkan penyerahan jaminan fidusia yang diterima dari Wawan.

2. Bahwa pemberi fidusia belum menyelesaikan kewajiban atau melunasi utang 
kepada pelawan.

3. Pelawan mendalilkan, sebagai pemilik kendaraan berdasarkan penyerahan jaminan fidusia yang diterima dari Wawan tidak terlibat langsung dalam tindak pidana tersebut, maka perampasan obyek fidusia oleh negara merupakan kekeliruan hukum dan bertentangan dengan UUD 1945

4. Berdasarkan surat perjanjian fidusia antara Pelawan dengan sdr. Wawan, maka secara hukum Pelawan adalah pemilik yang sah oleh karenanya pelawan berhak untuk menguasai, dengan deemikian penguasan obyek fidusia oleh terlawan tidak dibenarkan menurut hukum.

Berdasarkan dalil perlawan tersebut, pelawan mengajukan permohonan kepada majelis hakim perdata dalam perkara yang tercatat dalam register perkara nomor 18/ PDT.G/2015/PN Ktp.untuk :

1. Menyatakan sebagai pihak mempunyai legal statement untuk mengajukan gugatan perlawan.

2. Menyatakan pelawan sebagai pemilik yang sah dari kendaraan tersebut.

3. Memerintahkan terlawan untuk menunda pelaksanaan eksekusi terhadap kendaraan tersebut

4. Memerintahkan terlawan untuk menyerahkan kendaraan tersebut kepada pelawan

Selanjutnya Majelis hakim mepertimbangkan dalil-dalil pelawan yang pada pokoknya sebagai berikut :

1. Perjanjian fidusia yang diterimanya bersifat accesoir atau ikutan hakekatnya adalah obyek fidusia adalah agunan atau jaminan atas utang pemberi fidusia, berdasarkan history pembayaran, permberi fidusia tidak pernah menunggak atau cidera janji, sehingga hak milik obyek fidusia belum beralih kepada pelawan. Meskipun obyek fidusia telah dirampas oleh negara tetapi pemberi fidusia tetap memenuhi kewajibannya atas perjanjian pokok dengan penerima fidusia. Oleh karenanya dalil yang menyatakan bahwa pelawan sebagai pemilik sah kendaraan tersebut tidak berdasar dan tidak dapat diterima;

2. Putusan Pengadilan dalam perkara pidana Nomor : 95/Pid.Sus/2015/PN. Ktp. yang menyatakan HENDI HERIYADI Bin MAT JEMAN telah terbukti secara sah dan meyakinkan bersalah melakukan tindak pidana "Dengan sengaja mengangkut hasil hutan kayu yang tidak dilengkapi bersama-sama Surat Keterangan Sahnya Hasil Hutan" sebagaimana Pasal 12 huruf e jo pasal 83 ayat (1) huruf b UU RI Nomor : 18 Tahun 2013 Tentang Pencegahan Dan 
Pemberantasan Perusakan Hutan jo Pasal 55 Ayat (1) ke-1 KUHP. Sehingga Barang bukti berupa kendaraan tersebut dirampas untuk negara, adalah putusan yang benar dan telah mempunyai kekuatan hukum tetap, sehingga dalil pelawan yang menyatakan putusan Pengadilan dalam perkara pidana Nomor : 95/Pid. Sus/2015/PN. Ktp merupakan kekliruan hukum adalah tidak berdasar dan tidak dapat diterima;

3. Pasal 273 Ayat (3) KUHAP menyatakan "selain pengecualian sebagai mana tersebut Pasal 46, Jaksa menguasakan benda tersebut kepada kantor lelang negara dan dalam waktu tiga bulan untuk dijual lelang, yang hasilnya dimasukkan ke kas negara untuk dan atas nama jaksa”. sehingga Jaksa Penuntut umum melaksanakan penguasaan dan tindakan perampasan sebagaimana Putusan Hakim, oleh karenanya dalil yang disampakan oleh pelawan tidak berdasar dan tidak dapat diterima.

Berdasarkan pertimbangan tersebut majelis hakim Dalam Pokok Perkara menyatakan dan memutuskan :

1. Menolak gugatan Pelawan untuk seluruhnya ;

2. Menghukum Pelawan untuk membayar biaya yang timbul dalam perkara ini sebesar Rp. 2.711.000,00 (dua juta tujuh ratus sebelas ribu Rupiah).

Benang merah dari uraian di atas yaitu kreditor atau penerima fidusia masih mendapatkan perlingungan hukum yang mutlak sekalipun obyek fidusia yang diterimanya dinyatakan dirampas untuk Negara, hanya saja kedudukan sebagai kreditor yang diutamakan akan musnah atau terhapus jika obyek fidusia dirampas untuk Negara. Oleh karena itu penulis berpendapat bahwa dari pada membuang energy dan biaya sebaiknya kreditor tidak perlu mengajukan gugatan perlawan terhadap Pemerintah Cq. Kejaksaan RI. karena sebenarnya kreditor masih punya hak tagih, kecuali debitor cidera janji atau wanprestasi terhadap perjanjian pokoknya, kreditor dapat mengajukan gugatan perdata kepengadilan sekaligus meletakkan sita jaminan atas benda-benda milik debitor. Sita jaminan ini dimaksudkan agar kreditor mendapatkan jaminan pembayaran dari debitor jika gugatannya dikabulkan oleh Pengadilan. 


\section{Akibat hukum terhadap Pemenang Lelang atau Pembeli}

Konsep perlindungan hukum di Indonesia adalah pengakuan terhadap harkat dan martabat manusia yang bersumber pada Pancasila dan Undang-Undang Dasar 1945. Soetjipto Rahardjo mengemukakan bahwa perlindungan hukum adalah adanya upaya melindungi kepentingan seseorang dengan cara mengalokasikan suatu kekuasaan kepadanya untuk bertindak dalam kepentinganya tersebut. Selanjutnya dikemukakan pula bahwa salah satu sifat dan sekaligus merupakan tujuan dari hukum adalah memberikan perlindungan (pengayoman) kepada masyarakat. Oleh karena itu, perlindungan hukum terhadap masyarakat tersebut harus diwujudkan dalam bentuk adanya kepastian hukum. ${ }^{9}$

Azas-azas dalam lelang dan prosedur lelang merupakan perisai steakholder lelang dari segala permasalahan yang berpotensi muncul dalam pelaksanaan lelang. dengan asas keterbukaan seluruh lapisan masyarakat dapat mengetahui tentang rencana pelakasanaan lelang dan memberikan kesempatan yang sama kepadanya untuk menjadi peserta lalang, namun untuk menjadi peserta harus memenuhi persyaratan yang ditentukan Undang-Undang. Asas keadilan mewajibkan seluruh pemangku kepentingan dalam lelang untuk berlaku adil dalam proses pelaksanaan lelang sehingga dapat memenuhi rasa keadilan secara proporsional bagi setiap pihak yang berkepentingan. Asas kepastian hukum harus memberikan jaminan kepastian hukum dan perlindungan hukum baik terhadap obyek lelang maupun subyek lelang. Asas efisiensi akan menjamin bahwa pelaksanaan lelang akan dilaksanakan dengan cepat, biaya murah.

Kepastian hukum peserta lelang untuk ditetapkan sebagai Pembeli lelang berdasrakan Peraturan Menteri Keuangan Petunjuk Pelaksanaan Lelang Pasal 1 Angka 22 adalah pserta lelang yang menawar dengan penawaran tertinggi dan harus disahkan dan ditetapkan sebagai pemenang atau pembeli oleh Pejabat Lelang. setelah ditetapkan sebagai pemenang lelang atau pembeli, yang bersangkutan wajib melakukan pembayaran pokok lelang ditambah bea lelang dan biaya lainya yang

${ }^{9}$ Oetjipto Rahardjo, Permasalahan Hukum Di Indonesia (Alumni 1983).[121]. 
ditetapkan oleh pejabat lelang. disinilah momentum terjadinya peralihan hak atas benda yang di lelang dari penjual kepada pemenang lelang atau pembeli dan pada tahapan ini adalah momentum penyematan label pada pemenang lelang sebagai pembeli beritikat baik.

Pengertian itikad baik dapat diartikan sebagai jujur atau kejujuran. ${ }^{10}$ Adapun dalam Hukum Perdata kita tidak diterangkan secara jelas tentang apa sebenarnya yang dimaksud dengan itikad baik tersebut. Masalah itikad baik lebih berkaitan erat dengan tata kehidupan masyarakat, artinya menyangkut kesadaran hukum masyarakat yang memerlukan pembinaan dan pengaturan. ${ }^{11}$ Terkait dengan pengaturan pembeli beritikat baik dalam BW diatur pada pasal $1977 \mathrm{BW}$, pasal tersebut menyatakan :

"Terhadap benda bergerak yang tidak berupa bunga, maupun piutang yang tidak harus dibayar kepada si pembawa maka barang siapa yang menguasainya dianggap sebagai pemiliknya”.

Yurisprudensi Mahkamah Agung RI Nomor 821/K/Sip/1974 menyatakan bahwa pembelian dimuka umum melalui kantor lelang adalah pembeli beritikad baik, harus dilindungi undang-undang. Berdasarkan Yurisprudensi tersebut, maka pemenang lelang atau pembeli barang pada lelang eksekusi barang rampasan adalah pembeli beritikat baik.

Risalah Lelang adalah berita acara pelaksanaan lelang yang dibuat oleh Pejabat Lelang yang merupakan akta otentik dan mempunyai kekuatan pembuktian sempurna, dimaksudnya adalah pembuktian yang sempurna tentang apa yang dimuat didalamnya. Dalam hal ini Risalah Lelang mempuntai tiga macam kekuatatan pembuktian yaitu : (1) Kekuatan Pembuktian lahir, artinya bahwa apa yang tampak pada lahirnya, yaitu risalah lelang yang tampak seperti akta dianggap seperti akta sepanjang tidak terbukti sebaliknya; kekuatan (2) pembuktian formal ialah kepastian bahwa suatu kejadian yang adal didalam risalah lelang betul-betul dilakukan oleh Pejabat Lelang; kekuatan pembuktian materiel bahwa kepastian apa

\footnotetext{
${ }^{10}$ Djaja S. Meliala, Masalah Itikad Baik Dalam KUHPerdata (Binacipta 1987).[1].

11 ibid.[1].
} 
yang tersebut dalam risalah lelang itu benar-benar merupakan pembuktian yang sempurna dan sah terhadap para pihak yaitu penjual, pembeli dan berlaku untuk umum, kecuali ada pembuktian sebaliknya. ${ }^{12}$

Berdasarkan hal tersebut di atas Risalah Lelang bukan merupakan bukti kepemilikan kendaraan tersebut. Risalah lelang hanya sebagai bukti terjadinya proses jual beli dan terjadinya peralihan hak. Selanjutnya untuk mendapatkan bukti kepemilikan kendaraan tersebut, maka pemenang lelang harus mendaftarkan ulang kendaraan tersebut melalui Kepolisian Daerah setempat. Menjadi pertanyaan setelah dilakukan pendaftaran, apakah bukti kepemilikan kendaraan yang lama masih berlaku atau tidak, berdasarkan Surat Kakorlantas Nomor B/6021/XII/2016/ Korlantas, tanggal 5 DEsember 2016, perihal Pendaftaran Ranmor Hasil Lelang dengan Putusan Pengadilan Yang Berkekuatan Hukum Tetap, yang ditujukan kepada Para Kepala Kepolisian Daerah pada angka 3 huruf a menyatakan Bahwa:

"BPKB dan STNK yang tidak dijadikan Barang Bukti berarti statusnya blokir tindak pidana atau perdata, oleh karena itu apabila sudah ada putusan pengadilan dan risalah lelang secara hukum BPKB dan STNK yang masih berada pada pemilik tidak berlaku lagi”.

Berdasarkan uraian diatas, maka pemenang lelang atau pembeli benda atau barang kendaraan bermotor pada lelang eksekusi barang rampasan adalah pembeli yang beritikat baik dan dipastikan mendapatkan perlindungan hukum berupa jaminan kepastian hukum terjadinya peralihan hak milik atas benda dari Negara kepadanya. Jaminan kepastian hukum tersebut tertuang dalam berita acara lelang atau Risalah Lelang, selanjutnya pemenang lelang dapat mendaftarkan benda tersebut untuk mendapatkan bukti kepemilikan.

Tidak selamanya pemenang atau pembeli dalam Lelang Eksekusi Barang Rampasan mendapatkan perlindungan hukum terutama pemenang atau pembeli benda atau barang padalelang eksekusibarangrampasan yang sebelumnyamenjadiobjekfidusia sekalipun dalam pelaksanaan lelang tersebut sudah melalui prosedur yang sebenarnya dan pemenang sudah ditetapkan dengan terbitnya Risalah Lelang. Persoalan yang

\footnotetext{
${ }^{12}$ Rachmadi Usaman, Hukum Lelang (Sinar Grafika 2016).[158].
} 
menyebabkan pemenag lelang tidak mendapatkan perlindungan hukum dan kepastian hukum ketika Penerima Fidusia mengajukan gugatan pembatalan terhadap hasil lelang selanjutnya dalam putusannya pengadilan menerima gugatan tersebut dan menyatakan Lelang Eksekusi Barang Rampasan Batal Demi Hukum Adanya putusan pengadilan yang menyatakan hasil lelang batal demi hukum mengakibatkan terganggunya hak-hak yang dimiliki oleh pembeli beritikad baik atas benda yang dibelinya.

Merujuk kepada Yurisprudensi Mahkamah Agung RI Nomor 821/K/Sip/ 1974 seharusnya Negara hadir untuk memberikan jaminan kepada pemenang lelang sebagai pembeli beritikat baik bahwa yang bersangkuta dilindungi oleh hukum, setidaknya pemerintah mengeluarkan regulasi yang memberikan perlindungan hukum kepada pembeli pada pelaksanaan Lelang Eksekusi Barang Rampasan. Peraturan Menteri Keuangan Nomor 27/PMK.06/2017 tentang Petunjuk Pelaksanaan Lelang tidak mengakomodir permasalahan tentang perlindungan hukum kepada pemenang lelang eksekusi barang rampasan sebagai pembeli beriktikat baik.

Pernyataan di atas juga dikukung oleh pernyataan narasumber dari Kantor Kekayaan Negara dan Lelang Sidoarjo yang menyatakan bahwa pada prinsipnya Kekayaan Pelayanan Kekayaan Negara dan Lelang hanya sebagai perantara perjadinya jual beli barang rampasan yang sebelumnya menjadi obyek fidusia, KPKNL sendiri tidak memiliki payung hukum untuk melindungi pemenang lelang apabila pada kenyataannya lelang dinyakan Batal Demi Hukum oleh Hakim, seharusnya yang bertanggung jawab adalah penjual, karena sebagai penjual harus bertanggung jawab terhadap cacat-cacat yang tersembunyi. Selain itu Perturan Menteri Kuangan Nomor : 27/KMK.06/2016, sudah mengatur tentang tanggung jawab penjual, kemudian terkait dengan pengembalian uang pembayaran pokok lelang dan bea lelang yang sudah dibayarkan pembeli kepada Negara, bea lelang akan kami kembalikan, dan jika putusan Pengadilan menyatakan pokok lelang harus dikembalikan kepada pembeli, saya yakin Kejaksaan akan mengembalikan pokok lelang tersebut: ${ }^{13}$ Sidoarjo'.

${ }^{13}$ Yoyok M Susanto, 'Kepala Seksi Pelayanan Lelang Kantor Kekayaan Negara Dan Lelang 


\section{Kesimpulan}

Perjanjian jaminan fidusia merupakan perjanjian bersifat accseoir yang melahirkan hak kebendaan dan memberikan kedudukan yang diutamakan kepada Penerima Fidusia terhadap kreditor lainnya. Namun demikian kokohnya hak kebendaan dan kedudukan yang diutamakan kepada Penerima Fidusia terhadap kreditor lainnya tersebut akan runtuh jika obyek jaminan fidusia tersebut dinyatakan dirampas untuk negara. Akibat hukum perampasan obyek fidusia untuk Negara adalah berakhirnya perjanjian jaminan kebendaan dan terjadinya peralihan hak milik atas obyek fidusia tersebut kepada Negara. Namun demikian kreditor atau penerima fidusia tetap mendapatkan perlindungan hukum yang mutlak karena berakhirnya perjanjian jaminan kebendaan tersebut tidak serta merta menghapus perjanjian pokok, kreditor masih mempunyai hak tagih yang bersifat pribadi terhadap debitor sebagaimana diatur dalam pasal 1131 BW. Eksekusi terhadap Barang Rampasan yang sebelumnya menjadi obyek fidusia dilakukan dengan menjual secara Lelang dengan jenis Lelang Eksekusi Barang Rampasan. Berdasarkan azas lelang seharusnya Lelang Eksekusi Barang Rampasan dapat memberikan perlindungan hukum dan memberikan jaminan kepastian hukum bagi pemenang lelang atau pembeli atas barang yang dibelinya, tetapi hal ini tidak bisa dinikmati oleh pemenang atau pembeli dalam Lelang Eksekusi Barang rampasan yang sebelumnya menjadi Obyek Fidusia. Persoalan yang menyebabkan pemenang lelang tidak mendapatkan perlindungan hukum dan kepastian hukum ketika Penerima Fidusia mengajukan gugatan pembatalan terhadap hasil lelang selanjutnya dalam putusannya Pengadilan menerima gugatan tersebut dan menyatakan Lelang Eksekusi Barang Rampasan Batal Demi Hukum Adanya putusan pengadilan yang menyatakan hasil lelang batal demi hukum mengakibatkan terganggunya hak-hak yang dimiliki oleh pembeli beritikad baik atas benda yang dibelinya.

\section{Daftar Bacaan}

\section{Buku}

Djaja S. Meliala, Masalah Itikad Baik Dalam KUHPerdata (Binacipta 1987). 
Moch I, Pengantar Hukum Jaminan Kebendaan (PT Revka Petra Media 2016).

Pardede M, Implementasi Jaminan Fidusia Dalam Pemberian Kredit Di Indonesia 2006 (Badan Pembinaan Hukum Nasional Departemen Hukum Dan HAM-RI 2006).

Rahardjo O, Permasalahan Hukum Di Indonesia (Alumni 1983).

Trisadini Prasastinah Usanti LB, Hukum Jaminan (Revka Petra Media 2016).

Usaman R, Hukum Lelang (Sinar Grafika 2016).

\section{Hasil Wawancara}

Susanto YM, 'Kepala Seksi Pelayanan Lelang Kantor Kekayaan Negara Dan Lelang Sidoarjo'.

\section{Perundang-undangan}

Vendu Reglement (Peraturan Lelang) Staatsdlad1908:198.

Burgelijk Wetbook.

Undang-Undang No. 42 Tahun 1999 tentang Jaminan Fidusia.

Undang-Undang Nomor 16 Tahun 2004 tentang Kejaksaan Republik Indonesia.

Peraturan Menteri Keuangan Nomor: 27/PMK.06/2016, Tentang Perubahan Atas Peraturan Menteri Keuangan Nomor 93 /PMK.06/2010 tentang Petunjuk Pelaksanaan Lelang.

Peraturan Direktur Jenderal Kekayaan Negara Nomor 02/KN/2017, Tentang Petunjuk Teknis Pelaksanaan Lelang.

HOW TO CITE: Memet Achirius Sjafar, ‘Perampasan Obyek Fidusia dan Akibat Hukumnya' (2019) Vol. 2 No. 3 Notaire. 